\title{
A Review on the Emerging Asian Aquaculture Fish, the Malaysian Mahseer (Tor tambroides): Current Status and the Way Forward
}

\author{
Melinda Mei Lin Lau ${ }^{1}$ (D) Leonard Whye Kit Lim ${ }^{1}$ Sairatul Dahlianis Ishak ${ }^{2}$. \\ Ambok Bolong Abol-Munafi ${ }^{2} \cdot$ Hung Hui Chung ${ }^{1}$
}

Received: 12 April 2020/Revised: 8 April 2021/Accepted: 19 April 2021

(C) Zoological Society, Kolkata, India 2021

\begin{abstract}
The Malaysian mahseer (Tor tambroides) is a sport, ornamental and food all-in-one treasured aquaculture fish member of the Cyprinidae family. However, this freshwater riverine species is currently under the threats of habitat degradation and overfishing, apart from its poorly documented taxonomy. Despite its socio-economic significance, taxonomy confusion and conservation inadequacy, the knowledge gaps in some fields like the genomic landscape and biology are yet to be filled. In this comprehensive review, we presented an overview of all the past and current $T$. tambroides related research fields, namely morphology, population genetics, growth environment, reproduction, diet and nutrition, metagenome, mitogenome as well as conservation. Furthermore, we have included some future perspectives and recommendations for the advancement of the respective fields. It is anticipated that this review would be of great benefit to those planning to consolidate resources and work in tandem to pace the conservation and fish farming industry improvement endeavours.
\end{abstract}

Melinda Mei Lin Lau

mlaumeilin@gmail.com

$\triangle$ Leonard Whye Kit Lim

lwk11993@gmail.com

$\triangle$ Hung Hui Chung

hhchung@unimas.my

1 Faculty of Resource Science and Technology, Universiti Malaysia Sarawak, 94300 Sarawak, Malaysia

2 Higher Institution Centre of Excellence (HICoE), Institute of Tropical Aquaculture and Fisheries, Universiti Malaysia Terengganu, 21030 Kuala Neru, Terengganu, Malaysia
Keywords Mahseer - Aquaculture - Freshwater riverine · Conservation · Fish farming

\section{Introduction}

The Malaysian mahseer (Tor tambroides) is one of the most valuable riverine fishes in Southeast Asia. In addition to its food value, it is an important ornamental and sport fish. Its high nutritional value as well as unique flesh texture and taste are what made it highly sought after, earning it a top place among the most exorbitant fishes sold in the fish market (up to RM 400 per kg) (Ingram et al. 2005). The $T$. tambroides is one of the family members of Cyprinidae, sharing similar biogeographical distribution with $T$. douronensis and T. tambra across freshwaters of Indonesia and Malaysia (Pinder et al. 2019).

The natural habitat of T. tambroides is clear rapid waters with rocky bottoms (Shreshtha 1997). However, massive increment in destructive invasion events caused by human activities such as dam construction and overfishing had rendered these habitats unfeasible for the survival of the wild type fishes (Walton et al. 2017). This situation is made worse with the poorly documented conservation status and taxonomy data. The International Union for Conservation of Nature (IUCN) Red List of Threatened Species listed $T$. tambroides as data deficient (Kottelat et al. 2018; Pinder et al. 2019). Moreover, cryptic species of T. tambroides and $T$. douronensis have been reported previously (Nguyen et al. 2006), which further challenges the taxonomical classification. Therefore, looking into this matter, a comprehensive review encompassing the current status and future perspectives of $T$. tambroides researches, is necessitated to emphasize these dire predicaments and provide 
some constructive insights; this forms the aim and core of this review.

In this review, we presented an overview of the past and current $T$. tambroides researches, covering the fields of morphology, population genetics, growth environment, reproduction, diet and nutrition, metagenome, mitogenome as well as conservation. Besides, we have also included some future recommendations and perspectives to be instilled in the respective fields to highlight the knowledge gaps yet to be filled soon. It is expected that this review would help create enough attention and awareness just in time to accelerate conservation endeavours and soar the Malaysian mahseer fish farming industry to greater altitudes.

\section{Morphology}

Tor tambroides was first morphologically characterized by Bleeker (1854). This Tor species has a total of four dorsal spines, eight dorsal soft rays, three anal spines, five anal soft rays and 39-41 vertebrae (Bleeker 1854) (Fig. 1). Its median lobe (fleshy projection on the lower jaw) is long and more or less square and this lobe is situated on the lower lip reaching an imaginary line between the curves of the mouth (Bleeker 1854). Its upper lip appeared curled upwards and backwards and with a median lobe pointing upwards (Mohsin 1983). Dark longitudinal stripes along the side were absent in adult fish (Bleeker 1854). Its fins are yellow in colour during its juvenile growth stage and turns blackish in huge adults (Kottelat 1998). A sum of 20 gill rakers and nine branched dorsal-fin rays was detected in adult T. tambroides fishes (Bleeker 1854). Upon maturity, it can grow up to the maximum length of one metre, and the length usually ranges between 61 and $74.9 \mathrm{~cm}$ (Bleeker 1854).

The general morphologies used to differentiate species within the genus Tor are shape, size and length of the median lobe (Zhou and Cui 1996). Between the year 2007-2013, there have been several attempts to distinguish T. tambroides from its close relatives of the same genus in terms of scale colour and mouth structure. One of the

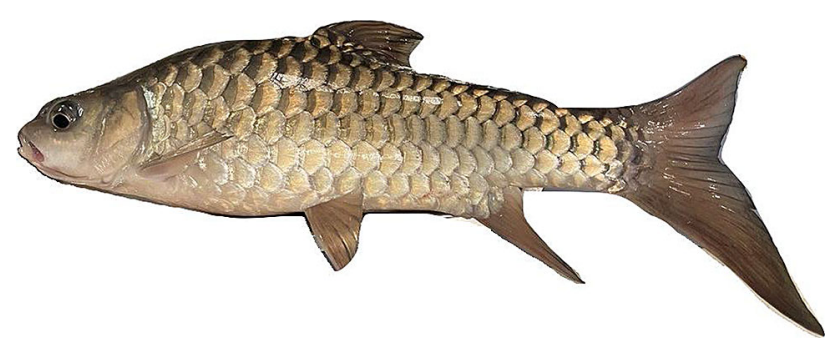

Fig. 1 The image of Malaysian mahseer fish notable attempts was from Siraj et al. (2007), which they had provided evidence that the scale colour variation (reddish and silver-bronze) observed in this fish came from the same species. Based on this evidence, they postulated that this attribute was orchestrated by environmental factors (Siraj et al. 2007) but there is no further solid evidence provided to date to support this claim. In 2008, Roberts and Khaironizam (2008) debunked the myth that environmental factors contributed towards the variation in mouth structure of this fish. A 66-day period growth investigation on $T$. tambroides fishes in different environmental conditions had yielded no mouth structure variation across all fishes (Roberts and Khaironizam, 2008).

The $T$. tambroides fishes are often misidentified as $T$. tambra fishes due to their highly similar morphologies. Between the year 2013 and 2017, the T. tambroides fishes was distinguished morphologically from its congeneric counterpart (T. tambra) via the length of the median lobe (Kottelat 2013). The T. tambra was characterised as the one having thin lips, short median lobe and rounded snout whereas $T$. tambroides was documented to have thick lips, long median lobe and pointed snout (Kottelat 2013). In 2015, the principal components analysis (PCA) attempted by Khaironizam et al. (2015) (utilizing both morphometric and meristic data) on Tor spp. showed no segregation of clusters across all morphotypes, indicating the events of polymorphism instead of speciation. Two years later, Walton et al. (2017) had provided cytochrome oxidase I gene phylogeny evidence that the median lobe length characteristic in Malaysia does not differentiate both the aforementioned Tor species. Instead, they proposed that the gill-raker amount is powerful enough to be utilized as a benchmark for this distinguishment, this statement holds true at least in the Pahang state of Malaysia (Walton et al. 2017). Nonetheless, they emphasized that detailed genetic analysis is crucial for accurate and precise species identification (Walton et al. 2017). In 2018, Zulfami et al. (2018) characterized the morphology of the $T$. tambroides from the aspect of axial skeleton. There were one os urostyles vertebrae, 18 pairs of ossa costales, 19 ossa abdominal vertebrae, 16 ossa caudal vertebrae and four axial vertebrae bones belonging to the weberian apparatus detected in this fish (Zulfami et al. 2018).

\section{Population Genetics}

There is a myriad of genetic markers such as microsatellites, random amplification polymorphic DNA (RAPD) markers, haplotypes, mitochondrial genes and mitogenomes being used as tools for $T$. tambroides population genetics studies. In the early stages of $T$. tambroides population studies, most researchers focused on distinguishing 
this species from other closely related species (such as $T$. douronensis and T. tambra) sampled from different geographical locations via the information obtained from a single gene or a set of genes or mitochondrial regions. In the recent years, microsatellites and mitogenomes are the preferred tools for more accurate $T$. tambroides biogeographical population genetic estimations.

Nguyen et al. (2006) was one of the first to initiate the population genetic investigation across $T$. tambroides and T. douronensis harvested from Limbang and Rejang Rivers of Sarawak, East Malaysia. They had successfully differentiated the two species mentioned above utilizing the $16 \mathrm{~S}$ ribosomal RNA region of mitogenome and surprisingly they also discovered a $T$. douronensis cryptic species (Nguyen et al. 2006). Esa et al. (2008) conducted a wider survey of $T$. tambroides population genetics using cytochrome oxidase I gene, encompassing both Peninsular Malaysia and East Malaysia. Despite the monophyletic status of all three mahseers ( $T$. tambroides, $T$. douronensis and Neolissochilus stracheyl) was evidenced in that study, they warned that this data should be employed with great caution due to the small $T$. tambroides sample size used. Not long after, Nguyen et al. (2008) had expanded the scale of $T$. tambroides population genetic examination to a broader range of geographical regions (Thailand, Malaysia, Vietnam, China, Pakistan, Sri Lanka, Indonesia, Nepal and India), included Tor species like T. khurdee and T. putitora, as well as utilized three mitochondrial DNA gene regions (ATPase 6 and ATPase 8 region, 16S ribosomal RNA region and cytochrome $b$ gene) instead of just one previously. As a result, they discovered that T. tambroides exhibited low genetic variations as compared to other Tor species investigated and this phenomenon is probably caused by population migrations during the periods of low Pleistocene sea levels (Nguyen et al. 2008).

In the recent years, Esa and Rahim (2013) utilized both the cytochrome oxidase I gene and microsatellites to reassess the $T$. tambroides population genetics across various localities of Peninsular and East Malaysia. Interestingly, they discovered a $T$. tambroides cryptic lineage (Haplotype ER8*) exclusively found within the EndauRompin (covering both Pahang and Johor state) population, and they postulated that it might be a hybrid species between T. tambroides and T. douronensis (Esa \& Rahim, 2013). Not long ago, Lim et al. (in press) employed 15 complete mitogenomes (13 protein-coding genes and two ribosomal RNA genes) of $T$. tambroides and T. tambra harvested from Indonesia (Java), Peninsular and East Malaysia to further improve the phylogenetic resolution of these species. The phylogenetic tree constructed revealed the clustering of $T$. tambroides fishes from Pahang state of Malaysia with $T$. tambra from the same state. They postulated that cryptic Tor fishes may be present in the Keniam River of Pahang state (Lim et al. in press).

\section{Growth Environment}

The deterioration of $T$. tambroides natural habitat and the increasing consumer demand for this fish flesh have driven the rapid emergence of the Malaysian mahseer farms. The success in culturing of this freshwater fish is greatly dependent on both the growth environment condition and seed quality (Dela Cruz 1982). In fact, it has been proven in many researches that the yield of the Malaysian mahseer increases proportionally with the optimal growth conditions provided.

In 2014, Lee et al. (2014) conducted a comprehensive microbiological and physiochemical survey on growth environmental water in seven randomly selected $T$. tambroides farms in Kuching, Sarawak, Malaysia. All physiochemical parameters such as biochemical oxygen demand (BOD), total ammonia nitrogen (TAN), $\mathrm{pH}$, temperature and dissolved oxygen (DO), fell within the accepted healthy range for optimal fish growth (Lee et al. 2014). On the microbiology side, a sum of 11 presumptive Enterobacteriaceae isolates belonging to nine Enterobacteriaceae genera, was unearthed. The isolated Enterobacteriacae are mostly human pathogens with few fish pathogens, which encompass Cedecea davisae, Vibrio fluvialis, Serratia odorifera, Brucella spp., Citrobacter braakii, Proteus vulgaris, Enterobacter cloacea, Erwinia spp., Citrobacter freundii, and Butiaxella agrestis (Lee et al., 2014). Among these, Citrobacter freundii and Enterobacter cloacae is believed to cause diseases in fishes. Lee et al. (2014) concluded that physiochemical factors may influence the microbiota in the fishponds, orchestrating the growth of the Malaysian mahseer fish.

The effect of temperature stress on T. tambroides fish growth has been tested by Nguyen (2015) and the result showed positive correlation. Nguyen (2015) evaluted the gene expression changes as the result of temperature stress on the juvenile Tor tambroides. The growth immune related genes selected for analysis were HSP70 (heat shock protein 70), GPx (glutathione peroxidase) and GHRl (growth hormone receptor 1). At the same time, the capability of probiotics $\left(10^{8}\right.$ colony forming unit per gram Bacillus subtilis) in aiding the fish to curb temperature stress was investigated. The HSP70 gene was up-regulated in liver at $38{ }^{\circ} \mathrm{C}$ by 6.38 -fold in probiotic treated group but down-regulated by 0.21 -fold in control group. GPx gene expressed 1.556 -fold higher in kidney at $11{ }^{\circ} \mathrm{C}$ for probiotic treated group but expressed 0.247 -fold lower in control group (Nguyen 2015). The GHRl gene expression did not differed significantly between the two tested groups 
(Nguyen 2015). They deduced that prebiotics inoculum facilitates $T$. tambroides growth performance and shields the fish against temperature stress.

Duangjai and Punroob (2018) examined the growth performance of $T$. tambroides in different types of cultured environments under constant physiochemical parameters such as nitrite concentration, salinity, turbidity, ammonia level, water temperature, nitrate level, total dissolved solids, conductivity and dissolved oxygen. The survival rates of fishes in all cultured environments were relatively high. The highest weight gain percentage $(110.11 \pm 24.48 \%)$, greatest average weight gain $(0.74 \pm 0.14 \mathrm{~g} /$ fish/day $)$, best specific growth rate $\left(0.82 \pm 0.13 \%\right.$ day $\left.^{-1}\right)$, highest mean final weight $(128.31 \pm 11.39 \mathrm{~g})$ and best feed conversion ratio $(3.51 \pm 0.01)$ were observed in fishes cultured in bamboo cage significantly, as compared to three other culture environments like nylon cage, screen-fishing net cage and pens culture (Duangjai and Punroob 2018). Das et al. (2018) investigated the temperature effects on oxygen consumption rate, gastric emptying time and growth of $T$. tambroides fishes under laboratory conditions. The highest specific growth rate $\left(0.71 \pm 0.10 \% \mathrm{day}^{-1}\right)$, greatest body weight gain $(7.25 \pm 1.14 \mathrm{~g})$, best daily growth rate $\left(4.70 \pm 0.20 \mathrm{~g} \mathrm{day}^{-1}\right)$, shortest gastric emptying time $(10 \mathrm{~h})$, as well as highest oxygen consumption rate $\left(5.5 \pm 0.53 \mathrm{~mL} \mathrm{O}_{2} \mathrm{~L}^{-1} \mathrm{~h}^{-1}\right)$ were all detected at $30^{\circ} \mathrm{C}$, as compared to temperature $22{ }^{\circ} \mathrm{C}, 24^{\circ} \mathrm{C}, 26^{\circ} \mathrm{C}$ and $28^{\circ} \mathrm{C}$ (Das et al. 2018). The optimum respiration rate determined for the Malaysian mahseer based on the temperature quotient $\left(\mathrm{Q}_{10}\right)$ was between $28{ }^{\circ} \mathrm{C}$ and $30{ }^{\circ} \mathrm{C}$. Ergo, they concluded that $30^{\circ} \mathrm{C}$ is the optimum water temperature that favours the $T$. tambroides fish growth the most.

\section{Reproduction}

In nature, the $T$. tambroides fishes exhibit upriver migration (spawning migration) during high-flood period and their spawning season is only limited to one or two months (Ingram et al. 2005). The reproduction researches of $T$. tambroides over the past two decades had come to fruition successes in terms of the search for the most effective and productive spawning method, enhanced ovulation, improved larval survival rate and establishment of hybrid species.

Ingram et al. (2005) was one of the pioneers in $T$. tambroides spawning researches, who had conducted threeyear spawning trials using hormone treatments and yielded significant breakthrough and insights. The most successful hormone treatment was the ovaprim $\left(0.5 \mathrm{ml} \mathrm{kg}^{-1}\right)$, the spawning induction success rate was greatly elevated with ovaplant (28-68 $\mathrm{g} \mathrm{kg} \mathrm{k}^{-1}$ ) pre-treatment two to seven months prior (Ingram et al. 2005). Formalin baths are vital for hatching enhancement as fungal manifestation was halted. The juvenile T. tambroides fishes had grown to 142-179 g (maximum $270 \mathrm{~g}$ ) within the 60 weeks period (Ingram et al., 2005). Ingram et al. (2007) further investigated on several aspects of T. tambroides breeding performance in captivity. It was found that some individual broodfish has achieved a time window between successive strippings in as short as 30 days and had gone through as much as 11 strippings throughout the study timeframe (Ingram et al. 2007). They deduced that the breeding performance of $T$. tambroides fishes was not affected by the continual egg strippings and numerous successive hydrophysations (multiple ovaprim injections) (Ingram et al. 2007).

Azuadi et al. (2011) attempted to enhance the ovulation of Malaysian mahseer in captivity via the removal of dopaminergic inhibition. The female fishes were pre-treated with ovaplant (23.4 to $44.9 \mu \mathrm{g} \mathrm{kg}^{-1}$ ) for six weeks before induction of different intramuscular injection inoculates. The ovatide $\left(0.5 \mathrm{~mL} \mathrm{~kg}^{-1} \mathrm{BW}\right)$ treatment produced highest total hand-stripped eggs, ovulation rate and handstripped fecundity across other treatments like sGnRHa (10 $\mu \mathrm{g} \mathrm{kg}^{-1}$ BW), DOM (5 $\mu \mathrm{g} \mathrm{kg}^{-1}$ BW), sGnRHa + DOM $\left(10 \mu \mathrm{g} \mathrm{kg}^{-1} \mathrm{BW}+5 \mu \mathrm{g} \mathrm{kg}^{-1} \mathrm{BW}\right)$ and control $(0.9 \% \mathrm{NaCl})$ (Azuadi et al. 2011). The highest fertilisation rate, hatching and larval survival rate as well as high quality eggs and larvae were observed in the sGnRHa + DOM group while no ovulation was induced in the DOM and saline group (Azuadi et al. 2011). The deduction made in their study is that dopaminergic inhibition shielded female T. tambroides fishes from ovulation.

One recent notable breakthrough in the field of T. tambroides reproduction research is none other than the establishment of a new hybrid species. Ismail et al. (2019) had successfully crossbred Malaysian red mahseer $T$. tambroides male with silver barb Barbonymous gonionotus female via induced breeding, as one of a concerted effort to diminish the pressure in its fisheries. The mouth of the resultant larvae was shut at hatching; mouth opening and movement commenced as early as 3 days after hatching (Ismail et al. 2019). At the same time frame, the taste buds began functioning and grew in amount as fish ages. Three days later, taste buds were found abundantly at the mouth cavity. A polynomial association was detected across the mouth gap and total mouth length as the fish was observed within the 23-day time window larviculture (Ismail et al. 2019). Ismail et al. (2020) continued to characterize the $T$. tambroides hybrid larvae until the end of its larval stage (18-21 days after hatching), and the survival rate was surprising high at $95 \%$, despite the fact that the larval hatching rate is below 5\%. The morphology and fastgrowing trait of this hybrid fish closely mirrors its maternal 
parent whereas its slightly lengthier body resembles that of its paternal parent (Ismail et al. 2019, 2020). Further investigations on its nutritional needs of this hybrid fish are on-going (Ismail et al. 2020).

\section{Diet and Nutrition}

The Malaysian mahseer is an omnivorous feeder, it forages on molluscs, plant, small fish and insects. Interestingly, it has a unique food preference towards fruits with high protein-energy content such as the illipe (fruit of Shorea macrophylla) (Abdul Rahman and Basri 2013; Kamarudin et al. 2014). It is widely deemed that the unique taste of the Malaysian mahseer flesh is contributed by the consumption of illipe fruit (Frost and Sullivan 2015). Another interesting point of view is that formulated feed fed $T$. tambroides larvae were superior to its live feed fed counterparts in terms of polyunsaturated fatty acids level and RNA/DNA ratio (Asaduzzaman et al. 2016). One imperative aspect to take note when feeding the Malaysian mahseer is the feed conversion ratio, which is the lowest at feeding frequency of once or twice daily in comparison to five times daily. The T. tambroides diet and nutrition research field is subdivided into two major branches: the investigation on the dietary needs of the fish as well as the fish feed formulation, both covering major sources of food, namely protein, lipid, carbohydrate and probiotics.

The protein requirement of $T$. tambroides fry is relatively higher than that of common carp (Yilmaz et al. 2005), tilapia and catfish fry but appeared to be similar to that of other riverine carp such as T. putitora (Hossain et al., 2002). $\mathrm{Ng}$ et al. (2008) determined the best dietary protein level for $T$. tambroides fingerlings for maximum growth rate to be at $48 \%$ (26 mg protein $\mathrm{kJ}^{-1}$ ), over the tested range of 30 to $50 \%$ dietary protein levels. Another crucial finding from this study is that elevating the dietary lipid concentration by $10-15 \%$, at dietary protein levels below $48 \%$, did not spare protein for fish growth as high dietary energy was already provided in all the diets $(\mathrm{Ng}$ et al. 2008). Similar results were obtained by Misieng et al. (2011) whereby the $40 \%$ dietary protein yielded the significantly lowest feed conversion ratio $(2.19 \pm 0.163)$ in $T$. tambroides fingerlings, over 30, 35, 45 and 50\% dietary protein levels. However, Misieng et al. (2011) left an open window stating that the growth rates of the fingerlings are also affected by different spawning trials.

The T. tambroides is classified as semi-fatty fish as it contains $4.6-5.2 \%$ of muscle crude lipid and a typical fatty fish has 5-8\% lipid in their edible tissue (Özogul and Özogul, 2007). A dietary n-3 to n-6 PUFA ratio of less than 0.3 is recommended by $\mathrm{Ng}$ and Andin (2011) for Malaysian mahseer fingerlings. On top of that, $\mathrm{Ng}$ et al. (2008) recommended that the optimum dietary lipid for $T$. tambroides should be less than 5\%. Lipid levels of $10 \%$ and $15 \%$ will increase the dietary gross energy for about $1 \mathrm{~kJ}$ per $\mathrm{g}$ in diet, but do not show significant increase growth and feed utilisation efficiency ( $\mathrm{Ng}$ et al. 2008). Any additional dietary energy in the feed will be deposited as fat in the visceral cavity, liver and abdominal activity as there is no interaction between lipid and protein ( $\mathrm{Ng}$ et al. 2008; $\mathrm{Ng}$ and Andin 2011). This shows that there is a lack of protein-sparing action on dietary lipid ( $\mathrm{Ng}$ et al. 2008), as body lipid of the fish is mostly deposited by dietary carbohydrate (Ishak et al. 2016; Kamarudin et al. 2018). Bami et al. (2017) suggested the crude palm oil as the best lipid source for the Malaysian mahseer juvenile for its high 16:0 and 18:1n-9 levels apart from the moderate 18:2n-6 level, which aided in the effective utilization of energy sources. This lipid source governs the muscle tissue to maintain high concentrations of n-3 and n-6 LC-PUFA (long-chain polyunsaturated fatty acids) (Bami et al. 2017). On the side note, the $T$. tambroides juveniles retained the highest muscle n-6 and n-3 polyunsaturated fatty acids at $0 \%$ illipe oil as compared to $1.25,2.5,3.75$ and $5 \%$ illipe oil (Kamarudin et al. 2018). Nevertheless, it is the illipe oil that can give the special taste to the Malaysian mahseer flesh, as there is no adverse effect on whole body proximate composition and growth performance with the addition of illipe oil in the fish diet (Kamarudin et al. 2018), this creates an opportunity for farmers to offer superior-fed T. tambroides to meet the consumer's demand.

Research has been done to investigate on the effects of different dietary carbohydrate levels on Tor tambroides fingerlings growth in terms of body composition, liver histology as well as feed utilization efficiency (Ishak et al. 2016). The treatment tested in the study was four isocaloric (17.6 $\mathrm{kJg}^{-1}$ ) and iso-nitrogenous (40\% crude protein) diets with differing carbohydrate concentrations $(30 \%, 25 \%, 20 \%$ and $15 \%)$, fed twice daily at $4 \%$ body mass (Ishak et al. 2016). After 10 weeks of feeding trials, it was discovered that the dietary carbohydrate level significantly ( $p<0.05$ ) orchestrated the survival rate, feed conversion rate, specific growth rate, weight increment as well as all nutrient retention values (Ishak et al. 2016). The liver histology of fingerlings subjected to higher carbohydrate treatments depicted hypertrophy and mild hepatic steatosis. They concluded that $20 \%$ and $25 \%$ dietary carbohydrate concentrations yielded the best growth performance among all others (Ishak et al. 2016). Employing a second-order polynomial regression analysis model, the optimal dietary carbohydrate level for mehseer fingerlings was determined at $23.4 \%$ (Ishak et al. 2016). The $20 \%$ dietary carbohydrate concentration yielded the highest expression level of hepatic glucose-6-phosphate dehydrogenase (G6PD) gene compared to other carbohydrate treatments of $15 \% .25 \%$ 
and $30 \%$ in another study conducted by Ishak et al. (2020a). Moreover, it was also determined that the fry growth is halted at dietary carbohydrate levels exceeding $25 \%$. Among the dietary carbohydrate sources tested for the feasibility to be utilized as T. tambroides fry feed such as tapioca starch, sago, taro and corn starch, the corn starch stood out as the best carbohydrate source for the fry (Kamarudin et al. 2014). Another study had been done to compare three local crops: sago (Metroxylon sagu), cassava (Manihot esculenta) and taro (Colocasia escunlenta) as replacement for corn starch in production of extruded feed for T. tambroides (Ishak et al. 2020b). This group of researchers found out that all the tested starch sources are producing fairly equal quality to that of corn starch in the aspects of expansion ration, pellet durability index and floating index thus concluding the potential of these crops as starch sources in Malaysian mahseer aquafeed formulation (Ishak et al. 2020b).

The probiotics are one of the newly suggested food sources for the growth betterment of $T$. tambroides juvenile fishes. Asaduzzaman et al. (2018a) isolated three hostderived probiotics (Shewanella sp. AFG21, Bacillus sp. AHG22 and Alcaligenes sp. AFG22) from the gastrointestinal tract of the Malaysian mahseer. A $10^{8} \mathrm{CFU} \mathrm{g}{ }^{-1}$ concentration of each isolate strain was supplemented to $T$. tambroides juveniles for 90 days. As a result, the Malaysian mahseer juveniles fed with Alcaligenes sp. AFG22 depicted higher lipolytic, cellulolytic and proteolytic counts as well as greater villus area, villus length and villus width, as compared to the control (40\% crude protein and $10 \%$ lipid) (Asaduzzaman et al. 2018a). Asaduzzaman et al. (2018b) took a step further to investigate on the hypertrophic muscle progression and growth-associated gene expressions on the same abovementioned T. tambroides juvenile samples. Hypertrophic large diameter $(>50 \mu \mathrm{m}$ ) fibers (Class 50, Class 60 and Class 70) were significantly abundant in Alcaligenes sp. AFG22 and Bacillus sp. AHG22 fed T. tambroides juveniles while the hyperplastic small diameter $(\leq 0.10 \mu \mathrm{m})$ fibers (Class 10$)$ abundance was not affected by any probiotics tested (Asaduzzaman et al. 2018b). This is a clear indication that the elevated muscle fibers hypertrophy was the main driver for $T$. tambroides escalated growth rate, instead of muscle hyperplasia. Furthermore, the upregulation of both growth hormone and insulin-like growth factor 1 genes was observed in Alcaligenes sp. AFG22 and Bacillus sp. AHG22 fed T. tambroides juveniles (Asaduzzaman et al. 2018b). This study had successfully established both the aforementioned host-associated probiotics as prospective autochthonous probiotics for $T$. tambroides growth escalation in aquaculture (Asaduzzaman et al. 2018b).

\section{Metagenome}

The microbiota inhabiting in fish can be considered as an 'extra organ' due to its essential role in health, homeostasis, growth, organ development and immunological shied (O'Hara and Shanahan 2006). Most bacteria are usually not the closest to environmental bacteria, but more to those symbionts of other animal hosts (Sullam et al. 2012). There are two types of metagenomes characterized to date for $T$. tambroides, namely gut metagenome and sperm metagenome.

Tan et al. (2019) performed a gut metagenomic study on the Malaysian mahseer, targeting the $16 \mathrm{~S}$ ribosomal DNA V3-V4 hypervariable fragment. The most abundant bacterial phyla discovered were Bacteroidetes, Proteobacteria, Firmicutes and Fusobactria. The top five most abundant operational taxonomic units in wild Malaysian mahseer are Cetobacterium spp., Vibrio spp., Bacteroides spp., Peptostreptococcaceae family, and Phosphate solubilizing bacteria PSB-M-3 whereas the top five most abundant operational taxonomic units in captive $T$. tambroides are Peptostreptococcaceae family, Citrobacter spp., Turicibacter spp., Cetobacterium spp. and Aeromonadaceae family (Tan et al. 2019). The differences in gut microbiota between wild and captive fishes could be attributed to the differences in diet, as the diet of fish in the wild comprises mainly of carbohydrates. Probiotics such as Bacteroides spp. are actively involved in the higher carbohydrate metabolism function in wild fish, in contrast to that of fish in captivity (Tan et al. 2019). They suggested that the common bacteria found across both captive and wild $T$. tambroides, the Cetobactrium spp., formed the core microbiota in the gut while some other high abundance essential microbiota like Turicibacter spp., Citrobacter spp., Bacillus spp., and Bacteroides spp. are potential candidates for probiotics development in future (Tan et al. 2019).

A survey of sperm metagenome was conducted by Koh et al. (2019), targeting the V3-V5 region of 16S ribosomal DNA, on samples harvested from three different localities in Peninsular Malaysia, namely Universiti Malaysia Terengganu (UMT) and Ajil in Terengganu state as well as Kuantan in Pahang state. The phyla detected abundantly across the three localities are Firmicutes, Actinobacteria and Proteobacteria (Koh et al. 2019). Pelomonas sp., Salinisphaera sp. and Staphylococcus spp. were found in high abundance in all samples across three locations (Koh et al. 2019). Nevertheless, the UMT sperm samples depicted a distinctive microbiota makeup. The interrelationship between microbial diversity and sperm quality was evidenced in this study. This study shed lights on the 
possible candidates for sperm quality enhancement probiotics.

\section{Mitogenome}

The mitogenome sequencing is one pivotal gateway to the comprehensive elucidation of the underlying molecular evolution and population genetics of an organism (Chen et al. 2016; Chung et al. 2020a; Lim et al. 2019a). The mitogenome tells a story about how the same fish species may look different phenotypically when segregated geographically, as part of their adaptation strategy to survive in harsh environment (Chung et al. 2020b; Lim et al. 2018a). This maternally inherited organellar genome has been proven powerful in improving the phylogenetic resolution of some fishes with high cryptic diversity, especially those from the Cyprinidae family, when coupled with both morphometric and meristic data (Aminan et al. 2020). This is extremely useful in solving the taxonomical classification of a species as it facilitates conservation efforts (Chung et al. 2020c; Lim et al. 2020a).

The first $T$. tambroides mitogenome was sequenced by Norfatimah et al. (2014) from a sample harvested from Keniam River in Pahang state of Malaysia. This mitogenome is $16,690 \mathrm{bp}$ in length and it encompasses 22 transfer RNA genes, 13 protein-coding genes, D-loop control region and two ribosomal RNA genes. The GC content of this mitogenome was recorded at $42.84 \%$ and the GenBank accession number assigned to this mitogenome is JX444718.1 (Norfatimah et al. 2014). The phylogenetic tree constructed across 20 Cyprinidae and two outgroup species, revealed that $T$. tambroides does not form a cluster with any of the 20 family members but projected alone from the basal clade (Norfatimah et al. 2014).

Lim et al. (in press) further sequenced mitogenomes of five T. tambroides fishes (BK00, BK01, BK02, LTT4 and LTTF) harvested from the mahseer farm in Kuching, Sarawak (East Malaysia). The mitogenome lengths of these isolates were $16,577 \mathrm{bp}, 16,578 \mathrm{bp}, 16,581 \mathrm{bp}, 16,581 \mathrm{bp}$ and $16,582 \mathrm{bp}$ respectively. The GC content recorded across these five samples were $42.91 \%, 42.88 \%, 42.90 \%$, $42.90 \%$ and $42.86 \%$ respectively. One interesting finding on the GC contents across the seven T. tambroides and eight $T$. tambra fishes is that all $T$. tambroides mitogenomes have GC contents not more than $42.92 \%$ while all $T$. tambra mitogenomes have GC composition exceeding $42.92 \%$, suggesting that GC content may be used preliminarily to distinguish between these two species (Lim et al., in press). Albeit no monophyletic clade was formed in the phylogenetic tree construted, they unearthed that the Malaysian Pahang state T. tambroides and T. tambra fishes exhibited cryptic diversity (Lim et al., in press). They suggested that complete COX1, Cytb, ND2, ND4 and ND5 genes can be used to resemble the whole mitogenome based on haplotype analysis. In addition, they discovered three mitolineages among the East Malaysian Sarawak state $T$. tambroides fishes (Lim et al., in press).

\section{Conservation}

The T. tambroides is an endemic species found only in the freshwaters of Southeast Asia. This Southeast Asia native fish are abundantly distributed across Peninsular Malaysia, Borneo Island (which includes Sarawak and Sabah states of East Malaysia) and Indonesia. Currently, the IUCN (International Union for Conservation of Nature) Red List status of T. tambroides is Data Deficient (Kottelat et al. 2018; Pinder et al. 2019). A complete guideline for genetic management and conservation of $T$. tambroides and $T$. douronensis was drafted by De Silva et al. (2007) as countermeasure to the extinction of this fish species. In this section, we review the conservation efforts and policies implemented to prevent the extinction of wild $T$. tambroides.

In Indonesia, endangered fish species were listed under the Government Regulation no. 7/1999 (Larashati et al. 2019). Lake Toba is one of most essential aquatic biodiversity hotspots currently being protected as eco-tourism spot. The Samosir Regency local government has planned to develop one of the rivers flowing into Lake Toba (Bonan Dolok River) into an ecotourism in situ conservation site (Larashati et al. 2019). Larashati et al. (2019) surveyed the habitat of T. tambroides, T. dongnaiensis and N. stracheyi across Lake Toba and Bonan Dolok River. Physiochemical monitoring was conducted at several key locations to ensure the water temperature, dissolved oxygen and conductivity of these habitats are feasible for the survival of the fishes (Larashati et al. 2019). They concluded that all parameters tested were within the healthy range for the fishes. Moreover, they recommended that the local government should emulate the mahseer conservation efforts by India, which have converted mahseer conservation into ecotourism encompassing activities like recreational fishing, mahseer watching and fish sanctuaries (Baruah and Sarma 2018; Larashati et al. 2019).

In Malaysia, the federal and state laws that protect endangered fishes are Fisheries Act 1985 (Act 317), Fisheries Fisheries (Prohibition and Method of Fishing) Regulations 1980, Fisheries (e.g., Prohibition of Import of Fish) Regulations 1990, Fisheries (Prohibited Areas) Regulations 1994, Fisheries (Control of Endangered Species of Fish) Regulations 1999, and State Fisheries (Riverine) Rules. In fact, there are a total of ten voucher specimen depositories for fish to date, scattering across Peninsular 
Malaysia and East Malaysia (Ng et al. 2017). In Sarawak state, the local government once launched a Tagang System (fishing prohibiting system) in Terbat Mawang village (GPS coordinates: $0^{\circ} 55^{\prime} 33.2^{\prime \prime} \mathrm{N}, 110^{\circ} 31^{\prime} 32.4^{\prime \prime} \mathrm{E}$ ) located in proximity to Kedup River since 2003 (Ansley et al. 2017). This system restricted the suitable size for fishing and fishes can only be harvested two years after the fry release (Department of Agriculture Sarawak, 2019). The latest release of T. tambroides fry in this state was in July 2016, across local rivers at Kuching, Samarahan, Sri Aman, Betong, Sarikei, Mukah, Bintulu, Miri and Limbang (Mail 2014). In Sabah state, there are more than 240 Tagal System (a similar system to Tagang System) and these systems are monitored strictly by the Department of Fisheries Sabah (Wong et al. 2009). Under this system, each pre-assigned section of a river is labelled into three zones: red, yellow and green zones (Wong et al. 2009). The green zone is "open fishing zone" where fishing is permitted for all Tagal community members all year round under stringent Tagal regulations; no gillnets fishing authorized but only cast-netting and angling. The yellow zone is open once annually or biannually during community festivals and celebrations; encircling gillnets are allowed and the catch is shared among the community members after administrative costs deductions. The red zone is preserved exclusively for Tagal fishery resource conservation purposes and this zone is open for sports fishing upon the payment of entrance fees (RM 50/day and excluding the local guide fee of RM50/two guests from 0800 to 1600) (Wong et al. 2009).

\section{Conclusion and future perspectives}

The Malaysian mahseer Tor tambroides, a freshwater fish having high market value and demand for its unique taste, is currently facing threats leading to its population decline. Studies have been carried out on the biology of this fish in order to increase its population in the wild. Research is also going on with regard to the fish's growth environment, diet, breeding and conservation. However, lacunae in our undertstanding related to the fish's conservation have remained and these should be addressed by thorough investigations and effective regulations. For example, the morphological examination of $T$. tambroides should be coupled with genetic analysis for more precise verification step. Moreover, the population genetic survey should be conducted with larger sample size to reduce statistical errors and misrepresentations. Likewise, the growth environment feasibility of this species should be compared with that of in situ fish farming. More importantly, the reproduction of hybrid fish species should be monitored with utmost care and precaution to avoid any threat to the genetic integrity of its counterpart in the wild. A superior, illipe oil diet-fed farmed T. tambroides may be offered as an alternative to the wild types, and efforts should be made to isolate more probiotics to further improve the health of the fish. In this context, the metagenome and mitogenome study can be expanded to include fishes isolated from other localities within Southeast Asia. Finally, the conservation efforts for this fish can be further strengthened by implementing the government policies that support eco-education and eco-tourism.

Although the published reports discussed in this review on T. tambroides are far from complete, they represent the prime areas investigated so far. However, state of the art molecular studies in some key areas may help to boost conservation of this fish. As done in some other fishes of commercial value, research is needed in T. tambroides on whole nuclear and transcriptome sequencing ( $\mathrm{Hu}$ et al., 2015; Chung et al. 2020a; Lim et al. 2020b, c), cis regulatory elements (promoter and enhancer) gene regulation (Lim et al. 2018a, 2019b, c, 2021; Md Yusni et al. 2020; Yeaw et al. 2020; Lai et al. 2021), growth-related metabolic pathway study (Overturf et al. 2010; Lim et al. 2018b; Lim and Chung 2020) coupled with metabolic profiling of the fish flesh (Chang et al. 2016; Mabuchi et al. 2019).

Besides providing a comprehensive understanding of the scientific works done on this Tor species, we hope that this review would be helpful to infuse more resources, both human and financial, into Tor research to facilitate the conservation measures and to drive the Malaysian mahseer fish farming industry to greater heights.

Acknowledgement This work was fully funded by The Ministry of Higher Education, Malaysia through Fundamental Research Grant Scheme with grant number F07/FRGS/1872/2019 awarded to $\mathrm{H}$. H. Chung as well as Universiti Malaysia Sarawak Postgraduate Student Research Grant with grant number F07/PGRG/1900/2019 awarded to L. W. K. Lim.

\section{References}

Abdul Rahman, N.F., and M. Basri. 2013. Interactive efects of impeller speed and substrate molar ratio on synthesis of engkabang fat esters. International Journal of Chemistry, Environmental and Biological Sciences 1: 528-530.

Aminan, A.W., L.W.K. Lim, H.H. Chung, and B. Sulaiman. 2020. Morphometric analysis and genetic relationship of Rasbora spp. in Sarawak. Malaysia. Tropical Life Sciences Research 31 (2): 33-49.

Ansley, A., W.S. Kiong, and S.E. Sanggin. 2017. Tagang system and the benefits to the community at Kampung Terbat Mawang, Serian, Sarawak. Journal of Borneo Kalimantan 3: 16-17.

Asaduzzaman, M., M. Abdul Kader, M. Bulbul, A.B. Abol-Munafi, M.A. Ghaffer, and M. Verdegem. 2016. Biochemical composition and growth performances of Malaysian mahseer Tor tambroides larvae fed with live and formulated feeds in indoor nursery rearing system. Aquaculture Reports 4: 156-163. 
Asaduzzaman, M., S. Iehata, S. Akter, M.A. Kader, S.K. Ghosh, M.N.A. Khan, and A.B. Abol-Munafi. 2018a. Effects of host gutderived probiotic bacteria on gut morphology, microbiota composition and volatile short chain fatty acids production of Malaysian mahseer Tor tambroides. Aquaculture Reports 9: 53-61.

Asaduzzaman, M., E. Sofia, A. Shakil, N.F. Haque, M.N.A. Khan, D. Ikeda, and A.B. Abol-Munafi. 2018b. Host gut-derived probiotic bacteria promote hypertrophic muscle progression and upregulate growth-related gene expression of slow-growing Malaysian mahseer Tor tambroides. Aquaculture Reports 9: 37-45.

Azuadi, N.M., S.S. Siraj, S.K. Daud, A. Christianus, S.A. Harmin, S. Sungan, and R. Britin. 2011. Enhancing ovulation of Malaysian mahseer (Tor tambroides) in captivity by removal of dopaminergic inhibition. Journal of Fisheries and Aquatic Science 6: $740-750$.

Bami, M.L., M.S. Kamarudin, C.R. Saad, A. Arshad, and M. Ebrahimi. 2017. Effects of palm oil products on growth performance, body composition and fatty acid profile of juvenile Malaysian mahseer (Tor tambroides). Journal of Oil Palm Research 29: 387-400.

Baruah, D., and D. Sarma. 2018. Mahseer in Recreational Fisheries and Ecotourism in India. Aquaculture Asia Magazine 22: 3-10.

Bleeker (1854). Tor tambroides. Retrieved from https://www.fishbase.in/summary/12231.

Chang, Y., H. Hou, and B. Li. 2016. Identification of volatile compounds in codfish (Gadus) by a combination of two extraction methods coupled with GC-MS analysis. Journal of Ocean University of China 15: 509-514.

Chen, F., H. Ma, C. Ma, H. Zhang, M. Zhao, Y. Meng, H. Wei, and L. Ma. 2016. Sequencing and characterization of mitochondrial DNA genome for Brama japonica (Perciformes: Bramidae) with phylogenetic considerations. Biochemical Systematics and Ecology 68: 109-118.

Chung, H.H., L.W.K. Lim, Y. Liao, T.T.Y. Lam, and Y.L. Chong. 2020a. Sequencing and characterization of complete mitochondrial DNA genome for Trigonopoma pauciperforatum (Cypriniformes: Cyprinidae: Rasbora) with phylogenetic consideration. Tropical Life Sciences Research 31: 107-121.

Chung, H.H., C.K.A. Kamar, L.W.K. Lim, J.S. Roja, Y.L. Liao, T.T.Y. Lam, and Y.L. Chong. 2020b. Sequencing and characterization of complete mitogenome DNA of Rasbora tornieri (Cypriniformes: Cyprinidae: Rasbora) and its evolutionary significance. Journal of Genetics 99: 1-7.

Chung, H.H., C.K.A. Kamar, L.W.K. Lim, Y. Liao, T.T. Lam, and Y.L. Chong. 2020c. Sequencing and characterization of complete mitogenome DNA for Rasbora hobelmani (Cyprinidae) with phylogenetic consideration. Journal of Ichthyology 60: 90-98.

Das, S.K., and Md. NoorN., Kai, K. S., Juan, Q. Z., Mohd Iskandar, N. S., \& De, M. 2018. Effects of temperature on the growth, gastric emptying time, and oxygen consumption rate of mahseer (Tor tambroides) under laboratory conditions. Aquaculture Reports 12: 20-24.

De Silva, S.S., T.T. Thuy, S.Y. Sim, B. Ingram, and G. Gooley. 2007. Artificial propagation of semah, Tor douronensis and empurau, Tor tambroides, two species ofcommercial and conservation value to Sarawak. Malaysia: Guidelines for Genetic Management and Conservation.

Dela Cruz, C. R. (1982). Fishpen and cage culture development project in Laguna de Bay, Philippines. Retrieved from http://www.fao.org/docrep/field/003/AB755E/AB755E00.htm

Duangjai, E., and J. Punroob. 2018. Growth performance of mahseer fish (Tor tambroides) in different types of cultured environments. Eau Heritage Journal Science and Technology 12: 225-235.
Esa, Y., and K.A.A. Rahim. 2013. Genetic Structure and Preliminary Findings of Cryptic Diversity of the Malaysian mahseer (Tor tambroides Valenciennes: Cyprinidae) Inferred from Mitochondrial DNA and Microsatellite Analyses. BioMed Research International 170980: 1-14.

Esa, Y.B., S.S. Siraj, S.K. Daud, J.J.R. Ryan, A.A. Rahim, and S.G. Tan. 2008. Molecular systematics of mahseers (Cyprinidae) in Malaysia inferred from sequencing of a mitochondrial Cytochrome C Oxidase I (COI) gene. Pertanika Journal of Tropical Agricultural Science 31: 263-269.

Frost, C.D., and H. Sullivan. 2015. Functional and luxury foods market analysis. Australia, Adelaide: Market Analysis Functional Foods.

Hossain, M.A., N. Hasan, A.K.M. Azad Shah, and M.G. Hussain. 2002. Optimum dietary protein requirement of Mahseer, Tor putitora (Hamilton) fingerlings. Asian Fisheries Science 15: 203-214.

Hu, Y.C., C.K. Kang, C.H. Tang, and T.H. Lee. 2015. Transcriptomic analysis of metabolic pathways in milkfish that respond to salinity and temperature changes. PLOS ONE 10: e0134959.

Ingram, B., S. Sungan, G. Gooley, S.Y. Sim, D. Tinggi, and S.S. De Silva. 2005. Induced spawning, larval development and rearing of two indigenous Malaysian mahseer, Tor tambroides and Tor douronensis. Aquaculture research 36: 983-995.

Ingram, B., S. Sungan, D. Tinggi, S.Y. Sim, and S.S. De Silva. 2007. Breeding performance of Malaysian Mahseer, Tor tambroides and Tor douronensis broodfish in captivity. Aquaculture Research 38: 809-818.

Ishak, S.D., M.S. Kamarudin, E. Ramezani-Fard, and Y.A. Yusof. 2016. Effects of varying dietary carbohydrate levels on growth performance, body composition and liver histology of Malaysian ahseer fingerlings (Tor tambroides). Journal of Environmental Biology 37: 756-764.

Ishak, S.D., S.A. Razali, M.S. Kamarudin, and A.B. Abol-Munafi. 2020a. Data on PCR primer design for glucose 6-phosphate dehydrogenase gene and the effects of dietary carbohydrate levels on its expression in the liver of Malaysian mahseer (Tor tambroides). Data in Brief 31: 105916.

Ishak, S. D., Yusof, Y. A., \& Kamarudin, M. S. (2020b). Different starch sources affect physical characteristics of extruded feeds prepared for the Malaysian mahseer, Tor tambroides. Journal of Applied Aquaculture, 1-18.

Ismail, M.A., M.S. Kamarudin, F. Syukri, S.N. Ain, and K. Latif. 2019. Changes in the mouth morpho-histology of hybrid Malaysian mahseer (Barbonymus gonionotus $\bigcirc \times$ Tor tambroides $\left.{ }^{1}\right)$ during the larval development. Aquaculture Reports 15: 100210 .

Ismail, M., M.S. Kamarudin, F. Syukri, and K. Latif. 2020. Larval development of a new hybrid Malaysian Mahseer (Barbonymus gonionotus + × Tor tambroides $\widehat{\bigcirc})$. Aquaculture Reports 18: 100416.

Kamarudin, M. S., Ramezani-Fard, E., Ishak, S. D., De Cruz, C. R., Bami, M.L., Harris, M. H. I. \& Misieng, J. D. (2014). Feeding and nutrition of endangered mahseers: a review. Keynote Paper. In: International Conference of Aquaculture Indonesia. Universitas Padjajaran, Bandung.

Kamarudin, M.S., M.L. Bami, A. Arshad, C.R. Saad, and M. Ebrahimi. 2018. Preliminary study of the performance of crude illipe oil (Shorea macrophylla) as a dietary lipid source for riverine cyprinid Tor tambroides. Fisheries science 84: 385-397.

Khaironizam, M.Z., M. Zakaria-Ismail, and J.W. Armbruster. 2015. Cyprinid fishes of the genus Neolissochilus in Peninsular Malaysia. Zootaxa 3962: 139-157.

Koh, I.C.C., B.H.B. Nizam, Y.M. Abduh, A.B. Abol Munafi, and S. Iehata. 2019. Molecular characterization of microbiota 
associated with sperm of Malaysian mahseer Tor tambroides. Evolutionary Bioinformatics 15: 1-7.

Kottelat, M. 1998. Fishes of the Nam Theun and Xe Bangfai basins, Laos, with diagnoses of twenty-two new species (Teleostei: Cyprinidae, Baltoridae, Cobitidae, Colidae and Odontobutidae). Ichthyological Exploration of Freshwaters 9: 1-128.

Kottelat, M. 2013. The fishes of the inland waters of Southeast Asia: A catalogue and core bibliography of the fishes known to occur in freshwaters, mangroves and estuaries. The Raffles Bulletin of Zoology 27: 1-663.

Kottelat, M., A. Pinder, and A. Harrison. 2018. Tor tambroides. The IUCN red list of threatened species 2018: e.T187939A91076554. Retrieved from https://www.iucnredlist.org/species/187939/ 91076554

Lai, P.N., L.W.K. Lim, and H.H. Chung. 2021. Mutagenesis analysis of ABCB8 gene promoter of Danio rerio. Trends in Undergraduate Research. (in press).

Larashati, S., S.I. Ridwansyah, A.Y. Afandi, and Novianti R. 2019. Conservation efforts of ikan Batak (Tor spp. and Neolissochilus spp.) and its prospects to support ecotourism in Samosir Regency, North Sumatra Indonesia. International Conference on Tropical Limnology 535: 012041.

Lee, K.S., S. Lihan, F.F.G. Dasthagir, K.M. Mikal, F. Collick, and N.K. Hua. 2014. Microbiological and physicochemical analysis of water from Empurau fish (Tor tambroides) farm in Kuching, Sarawak, Malaysian Borneo. International Journal of Scientific \& Technology Research 3: 285-292.

Lim, L.W.K., and H.H. Chung. 2020. Salt tolerance research in sago palm (Metroxylon sagu Rottb.): Past, present and future perspectives. Pertanika Journal of Tropical Agricultural Science 43: 91-105.

Lim, L. W. K., H.H. Chung, M.M.L. Lau, F. Aziz, and H.M. Gan. Improving the phylogenetic resolution of Malaysian and Javan mahseer (Cyprinidae), Tor tambroides and Tor tambra: Whole mitogenomes sequencing, phylogeny and potential mitogenome markers. Gene. (in press).

Lim, L.W.K., H.H. Chung, Y.L. Chong, and N.K. Lee. 2018. A survey of recently emerged genome-wide computational enhancer predictor tools. Computational Biology and Chemistry 74: 132-141.

Lim, L.W.K., H.Y. Tan, A.W. Aminan, A.Q. Jumaan, M.Z. Moktar, S.Y. Tan, and B. Sulaiman. 2018. Phylogenetic and expression of ATP-binding cassette transporter genes in Rasbora sarawakenesis. Pertanika Journal of Tropical Agricultural Science 41: 1341-1354.

Lim, L.W.K., H.H. Chung, H. Hussain, and K. Bujang. 2019. Sago palm (Metroxylon sagu Rottb.): Now and beyond. Pertanika Journal of Tropical Agricultural Science 42: 435-451.

Lim, L.W.K., J.S. Roja, C.K.A. Kamar, H.H. Chung, Y. Liao, T.T.Y. Lam, and Y.L. Chong. 2019. Sequencing and characterization of complete mitogenome DNA for Rasbora myersi (Cypriniformes: Cyprinidae: Rasbora) and its evolutionary significance. Gene Reports 17: 100499.

Lim, L.W.K., H.H. Chung, Y.L. Chong, and N.K. Lee. 2019. Isolation and characterization of putative liver-specific enhancers in proboscis monkey (Nasalis larvatus). Pertanika Journal of Tropical Agricultural Science 42: 627-647.

Lim, L.W.K., H.H. Chung, Y.L. Chong, and N.K. Lee. 2019. Enhancers in proboscis monkey: A primer. Pertanika Journal of Tropical Agricultural Science 42: 261-276.

Lim, L.W.K., J.S. Roja, C.K.A. Kamar, H.H. Chung, Y. Liao, T.T.Y. Lam, and Y.L. Chong. 2020. Sequencing and characterisation of complete mitogenome DNA for Rasbora sarawakensis (Cypriniformes: Cyprinidae: Rasbora) with phylogenetic consideration. Computational Biology and Chemistry 89: 107403.
Lim, L.W.K., H.H. Chung, and H. Hussain. 2020. Organellar genome copy number variations and integrity across different organs, growth stages, phenotypes and main localities of sago palm (Metroxylon sagu Rottboll) in Sarawak, Malaysia. . Gene Reports 21: 100808.

Lim, L.W.K., H.H. Chung, and H. Hussain. 2020. Complete chloroplast genome sequencing of sago palm (Metroxylon sagu Rottb.): Molecular structures, comparative analysis and evolutionary significance. Gene Reports 19: 100662.

Lim, L.W.K., H.H. Chung, S.D. Ishak, and K. Waiho. 2021. Zebrafish (Danio rerio) ecotoxicological $A B C B 4, A B C C 1$ and $A B C G 2 a$ gene promoters depict spatiotemporal xenobiotic multidrug resistance properties against environmental pollutants. Gene Reports 23: 101110.

Mabuchi, R., A. Ishimaru, M. Tanaka, O. Kawaguchi, and S. Tanimoto. 2019. Metabolic profiling of fish meat by GC-MS analysis, and correlations with taste attributes obtained using an electronic tongue. Metabolites 9: 1.

Mail, R. (2014, September 14). Replenishing riverine fish stocks via tagang system. Borneo Post Online. Retrieved from https://www.theborneopost.com/2014/09/14/replenishingriverine-fish-stocks-via-tagang-system/.

Md Yusni, N.Z., L.W.K. Lim, and H.H. Chung. 2020. Mutagenesis analysis of ABCG2 gene promoter of zebrafish (Danio rerio). Trends in Undergraduate Research 3: a53-59.

Misieng, J.D., M.S. Kamarudin, and M. Musa. 2011. Optimum dietary protein requirement of Malaysian mahseer (Tor tambroides) fingerling. Pakistan Journal of Biological Sciences 14: 232-235.

Mohsin, M. 1983. Freshwater fishes of Peninsular Malaysia/AK Mohammad Mohsin, Mohd Azmi Ambak. Selangor, Malaysia: UPM Publisher.

Ng, W.K., and V.C. Andin. 2011. The Malaysian mahseer, Tor tambroides (Bleeker), requires low dietary lipid levels with a preference for lipid sources with high omega- 6 and low omega-3 polyunsaturated fatty acids. Aquaculture 322: 82-90.

Ng, W.K., N. Abdullah, and S.S. De Silva. 2008. The dietary protein requirement of the Malaysian mahseer, Tor tambroides (Bleeker), and the lack of protein-sparing action by dietary lipid. Aquaculture 284: 201-206.

Ng, C.K.C., A.C. Ooi, W.L. Wong, and G. Khoo. 2017. An overview of the status, trends and challenges of freshwater fish research and conservation in Malaysia. Journal of Survey in Fisheries Sciences 3: 7-21.

Nguyen, T. M. (2015). Effects of dietary probiotics and temperatures stress on growth and immunity related genes expression in Malaysian mahseer (Tor tambroides).Unpublished master's thesis, Universiti Malaysia Terengganu. Retrieved from http://umt-ir.umt.edu.my/xmlui/handle/123456789/5279.

Nguyen, T.T.T., S. Ingram, S. Sungan, G. Gooley, S.Y. Sim, D. Tinggi, and S.S. De Silva. 2006. Mitochondrial DNA diversity of broodstock of two indigenous mahseer species, Tor tambroides and Tor douronensis (Cyprinidae) cultured in Sarawak, Malaysia. Aquaculture 253: 259-269.

Nguyen, T.T.T., U. Na-Nakorn, S. Sukmanomon, and C. ZiMing. 2008. A study on phylogeny and biogeography of mahseer species (Pisces: Cyprinidae) using sequences of three mitochondrial DNA gene regions. Molecular Phylogenetics and Evolution 48: 1223-1231.

Norfatimah, M.Y., L.K. Teh, M.Z. Salleh, M.N. Mat Isa, and M.N. SitiAzizah. 2014. Complete mitochondrial genome of Malaysian mahseer (Tor tambroides). Gene 548: 263-269.

O'Hara, A.M., and F. Shanahan. 2006. The gut flora as a forgotten organ. EMBO Reports 7: 688-693.

Overturf, K., D. Sakhrani, and R.H. Devlin. 2010. Expression profile for metabolic and growth-related genes in domesticated and 
transgenic coho salmon (Oncorhynchus kisutch) modified for increased growth hormone production. Aquaculture 307: 111-122.

Özogul, Y., and F. Özogul. 2007. Fatty acid profiles of commercially important fish species from the Mediterranean, Aegean and Black Seas. Food Chemistry 100: 1634-1638.

Pinder, A.C., J.R. Britton, A.J. Harrison, P. Nautiyal, S.D. Bower, S.J. Cooke, and R. Raghavan. 2019. Mahseer (Tor spp.) fishes of the world: Status, challenges and opportunities for conservation. Reviews in Fish Biology and Fisheries 29: 417-452.

Roberts, T.R., and M.Z. Khaironizam. 2008. Trophic polymorphism in the Malaysian fish Neolissochilus soroides and other old world barbs (Teleostei, Cyprinidae). Natural History Bulletin of Siam Society 56: 25-53.

Shreshtha, T.K. (1997). The Mahseer in The Rivers of Nepal Disrupted by Dams and Ranching Strategies. Mrs. Bimala Shrestha, Kathmandu,Nepal, 259.

Siraj, S.S., Y.B. Esa, B.P. Keong, and S.K. Daud. 2007. Genetic characterization of the two colour-type of Kelah. Malaysia Applied Biology Journal 36: 23-29.

Sullam, K.E., S.D. Essinger, C.A. Lozupone, M.P. O'Connor, G.L. Rosen, R.O.B. Knight, and J.A. Russell. 2012. Environmental and ecological factors that shape the gut bacterial communities of fish: a meta-analysis. Molecular Ecology 21: 3363-3378.

Tan, C.K., I. Natrah, I.B. Suyub, M.J. Edward, N. Kaman, and A.A. Samsudin. 2019. Comparative study of gut microbiota in wild and captive Malaysian mahseer (Tor tambroides). Microbiology Open 8: e734.
Walton, S.E., H.M. Gan, R. Raghavan, A.C. Pinder, and A. Ahmad. 2017. Disentangling the taxonomy of the mahseers (Tor spp.) of Malaysia: Anintegrated approach using morphology, genetics and historical records. Reviews in Fisheries Science \& Aquaculture 25(3): 171-183.

Wong, J.Z., S. Etoh, and A.B. Sujong. 2009. Towards sustainable community-based fishery resources management: The Tagal system of Sabah, Malaysia. Fish for the People 7: 18-23.

Yeaw, Z.X., L.W.K. Lim, and H.H. Chung. 2020. Mutagenesis analysis of ABCB4 gene promoter of Danio rerio. Trends in Undergraduate Research 3: a44-52.

Yilmaz, E., A. Sahin, M. Duru, and I. Akyurt. 2005. The effect of varying dietary energy on growth and feeding behaviour of common carp, Cyprinus carpio, under experimental conditions. Applied Animal Behaviour Science 92: 85-92.

Zhou, W., and G.H. Cui. 1996. A review of Tor species from the Lancangjiang River (Upper Mekong River), China (Teleostei: Cyprinidae). Ichthyological Exploration of Freshwaters 7: 131-142.

Zulfami, I., Y. Akmal, and A.S. Batubara. 2018. The morphology of Thai's mahseer's Tor tambroides (Bleeker, 1854) axial skeleton (ossa vertebrae). Indonesian Journal of Ichthyology 18: 139-149.

Publisher's Note Springer Nature remains neutral with regard to jurisdictional claims in published maps and institutional affiliations. 